
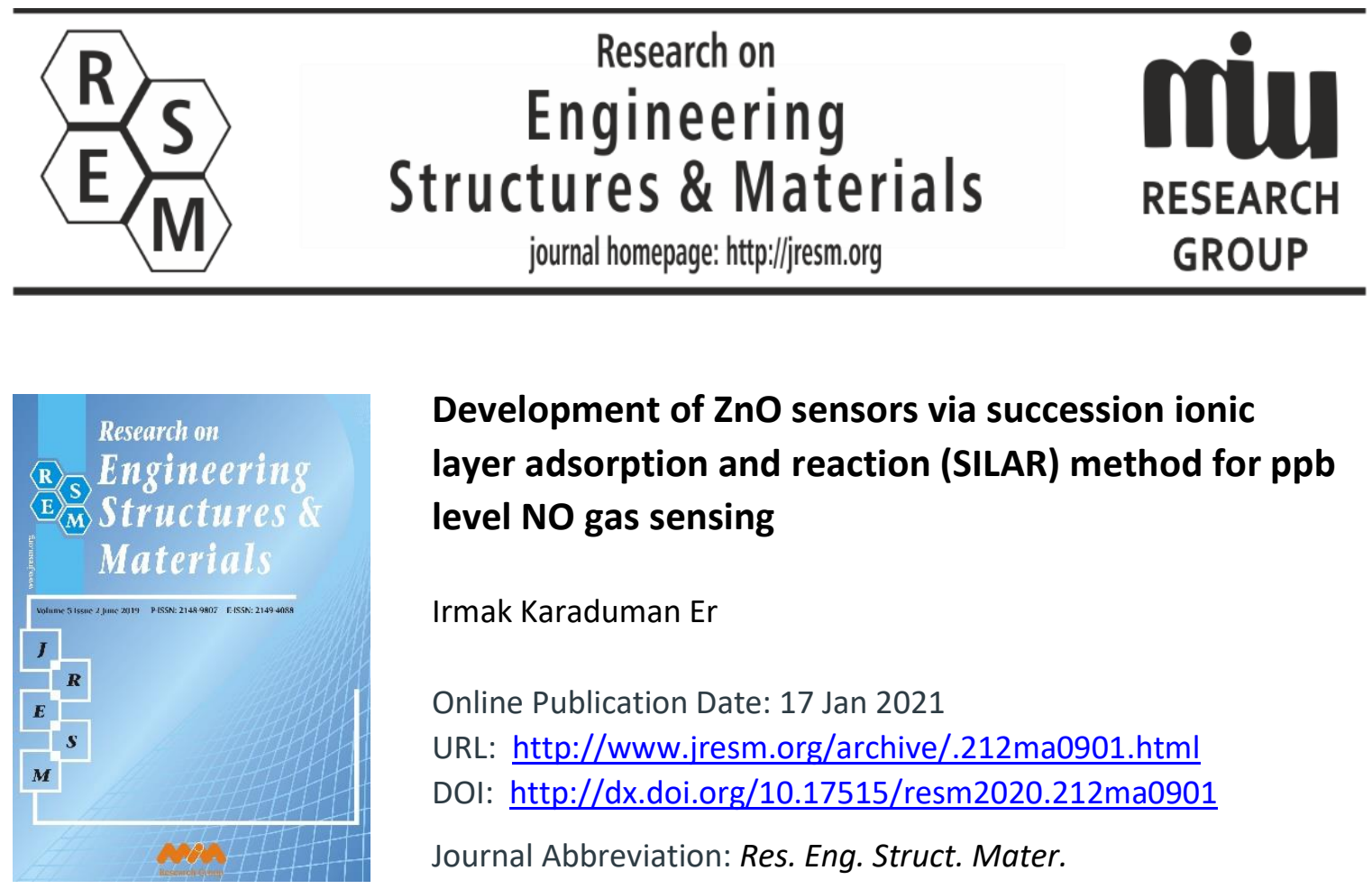

\title{
Development of $\mathrm{ZnO}$ sensors via succession ionic layer adsorption and reaction (SILAR) method for ppb level NO gas sensing
}

Irmak Karaduman Er

Online Publication Date: 17 Jan 2021

URL: http://www.jresm.org/archive/.212ma0901.html

DOI: http://dx.doi.org/10.17515/resm2020.212ma0901

Journal Abbreviation: Res. Eng. Struct. Mater.

\section{To cite this article}

Karaduman Er I. Development of ZnO sensors via succession ionic layer adsorption and reaction (SILAR) method for ppb level NO gas sensing. Res. Eng. Struct. Mater., 2021; 7(2): 259-272.

\section{Disclaimer}

All the opinions and statements expressed in the papers are on the responsibility of author(s) and are not to be regarded as those of the journal of Research on Engineering Structures and Materials (RESM) organization or related parties. The publishers make no warranty, explicit or implied, or make any representation with respect to the contents of any article will be complete or accurate or up to date. The accuracy of any instructions, equations, or other information should be independently verified. The publisher and related parties shall not be liable for any loss, actions, claims, proceedings, demand or costs or damages whatsoever or howsoever caused arising directly or indirectly in connection with use of the information given in the journal or related means.

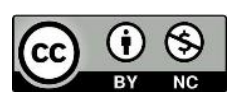

Published articles are freely available to users under the terms of Creative Commons Attribution - NonCommercial 4.0 International Public License, as currently displayed at here (the "CC BY - NC"). 


\title{
Research on Engineering Structures \& Materials \\ journal homepage: http://jresm.org
}

\section{Development of ZnO sensors via succession ionic layer adsorption and reaction (SILAR) method for ppb level NO gas sensing}

\author{
Irmak Karaduman Er \\ Department of Medical Services and Techniques, Eldivan Medical Services Vocational School, Çankırı Karatekin \\ University, Cankırl, Turkey \\ Article Info \\ Article history: \\ Received 01 Sep 2020 \\ Revised 18 Nov 2020 \\ Accepted 27 Dec 2020 \\ Keywords: \\ Gas Sensor; \\ NO Gas; \\ ppb Level

\section{Abstract} \\ In this work, the effects of Cd doping on the gas sensing properties of $\mathrm{ZnO}$ thin \\ films were synthesized by SILAR method and studied gas sensing characteristics \\ against NO, CO, ammonia, methanol and acetone, systematically. Whereas the \\ operating temperature of $\mathrm{NO}$ gas was found $90{ }^{\circ} \mathrm{C}, \mathrm{CO}$ and acetone were $150{ }^{\circ} \mathrm{C}$ \\ and $170{ }^{\circ} \mathrm{C}$. The response was not observed in methanol and ammonia gases. \\ Especially, it was observed that the response continued to increase as the \\ temperature increased for methanol gas. In addition, the $5 \% \mathrm{Cd}$ doped $\mathrm{ZnO}$ \\ sensor exhibits the excellent selectivity for NO compared to other test gases \\ as $\sim 12 \%$ at $0.01 \mathrm{ppm}$. NO gas sensing reactions are accelerated with Cd doping \\ because $\mathrm{Cd}$ doping was created increasing oxygen vacancies surface \\ chemisorbed oxygen species, and defects in the lattice.
}

(C) 2021 MIM Research Group. All rights reserved.

\section{Introduction}

Widely used as gas sensing material, $\mathrm{ZnO}$ is known for its high electron mobility and thermal stability $[1,2]$. ZnO has an optical transmittance of about $80 \%-90 \%$ in the visible region and an electrical resistivity in the region of $10^{-3}-10^{+2} \Omega$.cm. The simplicity of the fabrication of nanostructured $\mathrm{ZnO}$ makes it simple to adapt its surface with a high surface area. Besides, Morphology regulation is widely used in various fields, including transistors, sensors [3], electronic noses [4], and energy storage [5]. There are three different VO states in ZnO: neutral vacancy $\mathrm{V}_{0}{ }^{0}\left(\mathrm{~V}_{0 X}\right.$ in Kröger-Vink notation), singly ionized vacancy $\mathrm{V}_{0}{ }^{1+}\left(\mathrm{V}_{0}{ }^{\circ}\right)$, and ionized $2+$ state $\mathrm{V}_{0}{ }^{2+}\left(\mathrm{V}_{0} \cdot \bullet\right)$. They have different defect formation energies and electron states, which would result to the complex photoluminescence and electronic properties $[5,6]$. Therefore, gas sensing characteristcs can be improve with these defects. Especially, Different production methods can lead to different gas detection properties. The growth during the production methods, the dispersion to the surface, the structures that can be formed, the oxygen gaps, etc. features can change gas detection parameters.

Unlike other solution-based methods, SILAR technique is cheaper and practical, but also suitable for mass production [7-9]. SILAR technique is highly preferred in recent years due to its characteristics such as cheaper, simpler and less time spent during enlargement, since it does not require expensive equipment such as vacuum among semiconductor film growth methods [9]. SILAR is an aqueous solution technique involving a series of sequential reactions between substrate and solution, and is the immersion of the compound semiconductor to be grown on the material used as substrate into aqueous solutions containing ions of each type in a certain order [9]. In the SILAR method, it is possible to

Corresponding author: irmakkaradumaner@karatekin.edu.tr orcid.org/0000-0003-3786-3865; DOI: http://dx.doi.org/10.17515/resm2020.212ma0901 
control the thickness of the material to be grown on the substrate by determining the number of SILAR cycles and this is one of the most important parameters in the SILAR thin film growth method. As the number of cycles increases, the film thickness increases and a more stable structure is obtained. However, it is not appropriate to have too many SILAR cycles. Because when the film thickness reaches a certain value, ions will start to accumulate on the surface in the form of residue, as a result, ruptures will become easier and the quality of the film will decrease.

The doping in $\mathrm{ZnO}$ can change the electrical and dielectric characteristics and speed up the development of its practical applications [10]. The doping process depends on the nature of the fabrication technique and also the characteristics properties of dopant elements. The doping process is a substantial method to increase the sensing property of semiconductor sensors because of adjust the parameters of the crystal cell and the band structures of $\mathrm{ZnO}$ nanocrystals [11]. Therefore, $\mathrm{Cd}$ is one of the important doping elements to improve the sensitivity of gas sensors. One of the excellent doping material is $\mathrm{Cd}$. The oxygen adsorption of thin films can be enhanced with $\mathrm{Cd}$ atoms and this leads to increase gas reactions on the gas sensing surface. Therefore, The doping of $\mathrm{Cd}$ atom into $\mathrm{ZnO}$ has changed the electrical parameters of $\mathrm{ZnO}$ and increase its characteristics of the near-interface region [12-14].

As can be seen from Table 1, although the Cd doping is made for all studies, the sensing materials produced with different production methods can have different operating temperatures. Table 1 gives the different $\mathrm{Cd}$ doping gas sensing materials produced by different production methods.

Table 1. Different Cd doping gas sensing materials

\begin{tabular}{|c|c|c|c|c|c|}
\hline Materials & $\begin{array}{l}\text { Producing } \\
\text { Method }\end{array}$ & $\begin{array}{c}\text { Gas } \\
\text { Concentration }\end{array}$ & $\begin{array}{c}\text { Sensing } \\
\text { Response }\end{array}$ & $\begin{array}{c}\text { Operating } \\
\text { Temperature }\end{array}$ & References \\
\hline $\begin{array}{l}\text { Cd-ZnO Thin } \\
\text { Films }\end{array}$ & Spray Deposited & Acetone & 87 & $325^{\circ} \mathrm{C}$ & [15] \\
\hline $\begin{array}{l}\text { Cd-doped ZnO } \\
\text { Nanoparticles }\end{array}$ & $\begin{array}{l}\text { A Surfactant- } \\
\text { Mediated Method }\end{array}$ & n-butanol & 130 & $300^{\circ} \mathrm{C}$ & [16] \\
\hline Cd-doped ZnO & $\begin{array}{l}\text { Electrospinning } \\
\text { Method }\end{array}$ & 40 ppm CO & 95 & $135^{\circ} \mathrm{C}$ & [17] \\
\hline $\mathrm{ZnO} / \mathrm{CdO}$ & $\begin{array}{l}\text { Electrospinning } \\
\text { Method }\end{array}$ & $1.2 \mathrm{ppm} \mathrm{NO}$ & 226 & $215^{\circ} \mathrm{C}$ & [18] \\
\hline $\begin{array}{l}\text { Cd-doped ZnO } \\
\text { Thin Films }\end{array}$ & $\begin{array}{l}\text { RF Magnetron } \\
\text { Sputtered }\end{array}$ & $\begin{array}{c}50 \mathrm{ppm} \\
\text { Methanol }\end{array}$ & 130 & $50^{\circ} \mathrm{C}$ & [19] \\
\hline $\begin{array}{c}\text { ZnO:Cd } \\
\text { Nanorods }\end{array}$ & $\begin{array}{l}\text { Hydrothermal } \\
\text { Method }\end{array}$ & $\begin{array}{l}500 \text { ppm } \\
\text { Hydrogen }\end{array}$ & 1.67 & $80^{\circ} \mathrm{C}$ & [20] \\
\hline
\end{tabular}

In this work, the effects of $\mathrm{Cd}$ doping on the gas sensing properties of $\mathrm{ZnO}$ thin films were studied gas sensing characteristics against NO, CO, ammonia, methanol and acetone, systematically. The sensing characteristics of the as prepared samples were systematically measured. Fabricated sensors were tested against NO, CO, ammonia, methanol and acetone. In addition, the effect of the doping amount on gas sensing was investigated.

\section{Experimental Procedure}

To synthesize Cd doped $\mathrm{ZnO}$ thin films, aqueous zinc-ammonia complex ions $\left(\left[\mathrm{Zn}\left(\mathrm{NH}_{3}\right)_{4}\right]^{2+}\right)$ and aqueous cadmium-ammonia complex ions $\left(\left[\mathrm{Cd}\left(\mathrm{NH}_{3}\right)_{4}\right]{ }^{2+}\right)$ were chosen for the cation precursors, in which analytical reagents of $\mathrm{ZnCl}_{2}(\% 99)$ of $0.1 \mathrm{M}, \mathrm{CdCl}_{2}(\% 99)$ of $0.1 \mathrm{M}$ and concentrated ammonia $\left(\mathrm{NH}_{3}\right)(25-28 \%)$ were used. The double distilled water was used as a solvent. The molar ratio 1:10 of $\mathrm{Cd}-\mathrm{Zn}: \mathrm{NH}_{3}$ was obtained as a result of several experiments. The obtained $\left[\mathrm{Zn}\left(\mathrm{NH}_{3}\right)_{4}\right]^{2+}$ and $\left[\mathrm{Cd}\left(\mathrm{NH}_{3}\right)_{4}\right]^{2+}$ complexes were mixed in appropriate proportions. All the synthesis processing parameters by SILAR method were previously 
reported by the same authors [21-23]. The thin films of 1, 3, 5 and $7 \% \mathrm{Cd}$-doped ZnO were named as CZO1, CZO3, CZO5 and CZO7, respectively.

XRD measurements were done with Panalytical Empyrean X-ray Diffractometer $(\mathrm{Cu} K \alpha \lambda=$ 1.5405 radiation) and also SEM analysis were done the FEI Quanta FEG 450 model SEM with energy dispersive X-ray analysis (EDAX) attachment. Thickness of the films was measured by the gravimetric weight difference method using sensitive microbalance.

The gas detection performance of the sensors was tested with a gas detection measuring system. In our previous studies, detailed information about the gas detection measurement system is given $[21,22]$. The gas sensing measurements have been carried out at different concentrations and operating temperatures by monitoring the resistance changes. Dry air has been used as the carrier gas, which is $99.9 \%$ purity (dry air is the 'blank' gas used to purge the sensor). The flow rate of the dry air undergoing testing has been fixed at $500 \mathrm{~cm} 3$ min-1 during the measurements. Air flow rate, under the same conditions in order to observe the behaviour of different concentrations must be kept always constant. To ensure stable zero-level resistance in ambient air prior to exposure to gas the stabilization of the nanostructure resistance is important because it ensures stable zero level for gas sensing applications. For the corresponding operating temperature of the gas chamber, it is the prime requisite to stabilize the resistance in air atmosphere before ejecting the gas into the chamber. It indicates the resistance of nanostructure in air. The target gases and dry airflow rates have been controlled by computer controlled mass flow controllers (MKS series). The LakeShore 325 temperature controller with platinum resistance temperature detectors has been used to maintain a constant temperature. The sensor resistance has been continuously monitored with a computer controlled system using a Keithley 2400 source meter. The data have been collected in real-time using a computer with corresponding data acquisition hardware and software. Relative humidity has been kept constant (about 25\%) for all measurements, monitored by the Honeywell HIH-4000 humidity sensor [21,22].

\section{Results and Discussion}

In this study, the growth mechanism can be explained as below reactions;

$$
\begin{aligned}
& \mathrm{ZnCl}_{2}+2 \mathrm{NH}_{4} \mathrm{OH} \leftrightarrow \mathrm{Zn}(\mathrm{OH})_{2}+2 \mathrm{NH}_{4}^{+}+2 \mathrm{Cl}^{-} \\
& \mathrm{Zn}(\mathrm{OH})_{2}+4 \mathrm{NH}^{4+} \leftrightarrow 2\left[\mathrm{Zn}\left(\mathrm{NH}_{3}\right)^{4+}\right]^{2+}++2 \mathrm{H}_{2} \mathrm{O}+2 \mathrm{H}^{+} \\
& {\left[\mathrm{Cd}\left(\mathrm{NH}_{3}\right)^{4+}\right]^{2+}+4 \mathrm{H}_{2} \mathrm{O} \rightarrow \mathrm{Cd}(\mathrm{OH})_{2(\mathrm{~S})}+4 \mathrm{NH}_{4}^{+}+2 \mathrm{OH}^{-}}
\end{aligned}
$$

After that, The substrate is submerged in hot water, $\mathrm{Cd}(\mathrm{OH})_{2}$ is formed;

$$
\mathrm{Zn}(\mathrm{OH})_{2(\mathrm{~s})} \rightarrow \mathrm{ZnO}_{(s)}+\mathrm{H}_{2} \mathrm{O}
$$

As a result, $\mathrm{ZnO}$ thin film was grown on glass substrate by the SILAR method. A single cycle SILAR method is complete [24]. When the doping process is began, $\mathrm{Cd}(\mathrm{OH})_{2}$ solution is added to the solution in desired doping ratios and doping process is made. The solution mechanism is still under investigation. CdO formation mechanism is as follows [21-25];

$$
\begin{aligned}
& \mathrm{CdCl}_{2}+2 \mathrm{NH}_{4} \mathrm{OH} \leftrightarrow \mathrm{Cd}(\mathrm{OH})_{2}+2 \mathrm{NH}_{4}^{+}+2 \mathrm{Cl}^{-} \\
& \mathrm{Zn}(\mathrm{OH})_{2}+4 \mathrm{NH}^{4+} \leftrightarrow 2\left[\mathrm{Zn}\left(\mathrm{NH}_{3}\right) 4\right]^{2+}++2 \mathrm{H}_{2} \mathrm{O}+2 \mathrm{H}^{+}
\end{aligned}
$$

Figure 1 shows the XRD spectra of undoped and Cd-doped ZnO thin films. All peaks demonstrate the JCPDS data belonging to the hexagonal ZnO structure (Card No. 36-1451) $[26,27]$. Cd peaks increase with increasing doping concentrations, on the other hand, film 
quality decrease. This can be associated with the ionic radius, which $\mathrm{Cd}^{2+}(1.10 \AA)$ ion is greater than of the $\mathrm{Zn}^{2+}(0.74 \AA)$ ion. The calculated dislocation density, microstrain, interplanar distance, crystallite size, and FWHM of the peak values of the film can be seen in Table 2.

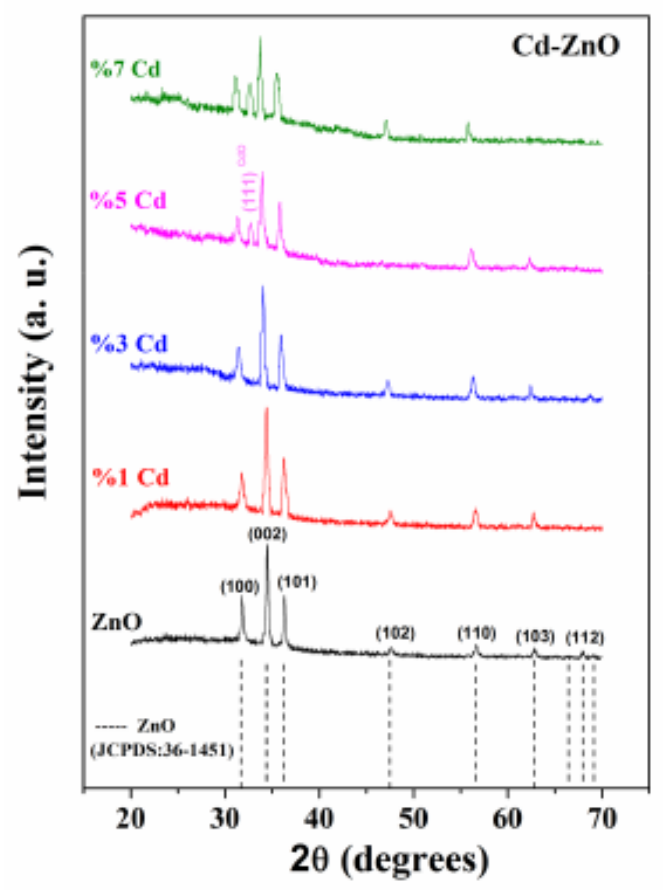

Fig 1. the XRD spectra of undoped and Cd-doped ZnO thin films 
Table 2. The calculated dislocation density, microstrain, interplanar distance, crystallite size, and FWHM of the peak values of the films

\begin{tabular}{|c|c|c|c|c|c|c|c|}
\hline Sample & (hkl) & $2 \theta$ & $\mathrm{D}(\mathrm{nm})$ & FWHM & $\begin{array}{c}\text { Interolanar } \\
\text { Distance; } \\
\text { d(Angstron) }\end{array}$ & $\begin{array}{c}\text { Dislocation } \\
\text { Density }(\delta) \\
\left(10^{-4}\right) \\
\end{array}$ & $\begin{array}{c}\text { Microstrain } \\
(\varepsilon)\end{array}$ \\
\hline \multirow{3}{*}{$\mathrm{ZnO}$} & $(100)$ & 31.85 & & 0.2476 & 2.8066 & \multirow{3}{*}{2.4189} & 0.2160 \\
\hline & (002) & 34.50 & 64.30 & 0.2508 & 2.5969 & & 0.2019 \\
\hline & (101) & 36.35 & & 0.2648 & 2.4687 & & 0.2016 \\
\hline \multirow{3}{*}{$\begin{array}{l}1 \% \text { Cd- } \\
\text { doped }\end{array}$} & $(100)$ & 31.81 & & 0.2810 & 2.8102 & \multirow{3}{*}{4.8590} & 0.2465 \\
\hline & $(002)$ & 36.30 & 45.37 & 0.3554 & 2.6004 & & 0.3059 \\
\hline & (101) & 36.30 & & 0.4306 & 2.4719 & & 0.3284 \\
\hline \multirow{3}{*}{$\begin{array}{l}\text { 3\% Cd- } \\
\text { doped }\end{array}$} & $(100)$ & 31.49 & & 0.2266 & 2.8376 & \multirow{3}{*}{4.4742} & 0.2064 \\
\hline & $(002)$ & 34.08 & 47.28 & 0.3407 & 2.6270 & & 0.2779 \\
\hline & (101) & 35.99 & & 0.4033 & 2.4927 & & 0.3298 \\
\hline \multirow{4}{*}{$\begin{array}{l}5 \% \text { Cd- } \\
\text { doped }\end{array}$} & $(100)$ & 31.37 & & 0.3045 & 2.8486 & \multirow{4}{*}{5.7273} & 0.2711 \\
\hline & (111) & 32.69 & 4170 & 0.3694 & 2.7363 & & 0.3149 \\
\hline & $(002)$ & 34.04 & 41.17 & 0.3854 & 2.6306 & & 0.3147 \\
\hline & (101) & 35.84 & & 0.3648 & 2.5028 & & 0.2820 \\
\hline \multirow{4}{*}{$\begin{array}{l}\text { 7\% Cd- } \\
\text { doped }\end{array}$} & $(100)$ & 31.16 & & 0.3872 & 2.8672 & \multirow{4}{*}{5.6915} & 0.3471 \\
\hline & (111) & 32.63 & 1102 & 0.3541 & 2.7411 & & 0.3024 \\
\hline & $(002)$ & 33.72 & 41.92 & 0.3838 & 2.6551 & & 0.3166 \\
\hline & (101) & 35.54 & & 0.3202 & 2.5233 & & 0.2497 \\
\hline
\end{tabular}

It is seen that the crystallite-size is decreased with increase of Cd concentration. The crystalline size were calculated $64.30 \mathrm{~nm}, 45.37 \mathrm{~nm}, 47.28 \mathrm{~nm}, 41.79 \mathrm{~nm}$ and $41.92 \mathrm{~nm}$ for $1 \%$ at $\mathrm{Cd}, 3 \%$ at $\mathrm{Cd}, 5 \%$ at $\mathrm{Cd}$, and $7 \%$ at $\mathrm{Cd}$-doped $\mathrm{ZnO}$ films respectively. The difference in ionic radius between $\mathrm{Cd} 2+$ and $\mathrm{Zn} 2+$ leads the lattice distortion. Dislocation density $(\delta)$ can be thought of as a measure of crystallinity $[28,29]$. The best crystalline structure shows for undoped $\mathrm{ZnO}$ compared to doping ones. Thickness of the films was calculated by the gravimetric weight difference method in terms of deposited weight of all films on the glass substrate, per unit area $\left(\mathrm{g} / \mathrm{cm}^{2}\right)$. Thickness of the films were found $90 \mathrm{~nm}, 95 \mathrm{~nm}, 82 \mathrm{~nm}$ and $102 \mathrm{~nm}$ for $1 \%$ at $\mathrm{Cd}, 3 \%$ at $\mathrm{Cd}, 5 \%$ at $\mathrm{Cd}$, and $7 \%$ at Cd-doped $\mathrm{ZnO}$ films respectively. These results show that the thickest sample is $1 \%$, but the thinnest sample is $5 \%$ so $\mathrm{Cd}$ dopant effect to the growth of samples by SILAR method.

The SEM images of the thin films are shown in Figure 2. As a result of SEM analysis, information about the roughness, homogeneity, adhesion of the film and surface defects can be obtained. The images show a general view of the morphology of Cd-doped $\mathrm{ZnO}$ films. SEM images of (a) \% 1, (b) $3 \%$ (c) $5 \%$ and (d) $7 \%$ Cd-doped ZnO thin films. The polycrystalline structure is revealed from the SEM micrographs. The films are porous as evident from absence of close packed morphology [30]. Such agglomeration makes it difficult to evaluate the grain size from SEM images. Figure 3 presents the EDAX analysis of Cd doped ZnO thin films. The EDAX analysis shows the presence of Zn, Sn and 0 elements in the films. The rates of Cd-doping are seen in EDAX analysis. Also, the presence of $\mathrm{Si}$ and Ca elements in the spectra may be caused by the substrate. It can be come from the glass substrate. 


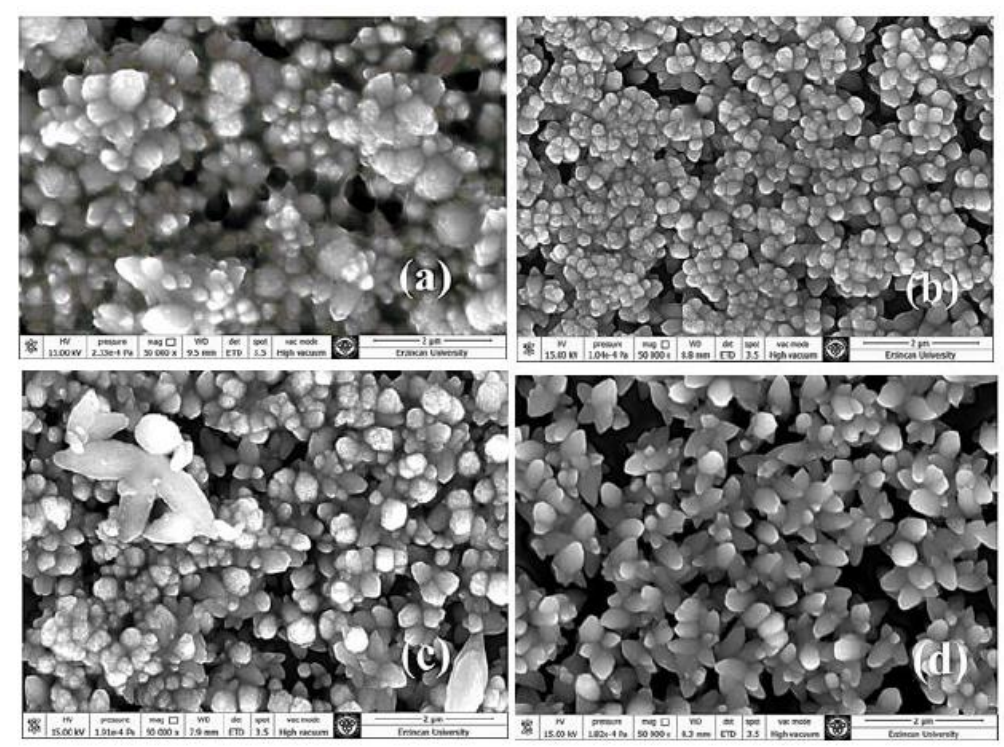

Fig 2. The SEM images of $1 \%$ (a), $3 \%$ (b), $5 \%$ (c) and $7 \%$ (d) Cd doped ZnO thin films
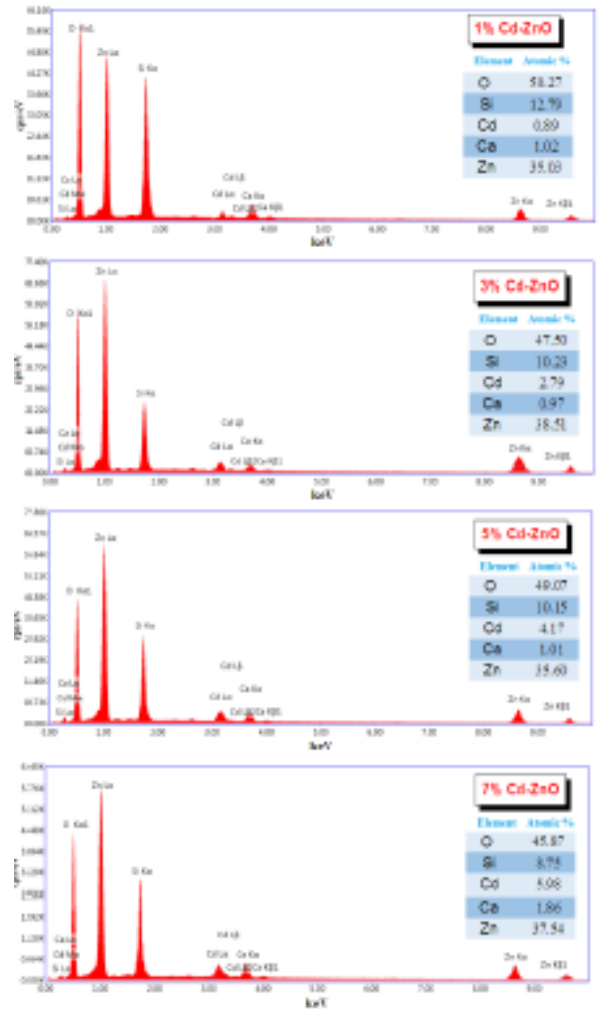

Fig 3. the EDAX analysis of Cd doped ZnO thin films 
The optical absorption spectrum of the $\mathrm{Cd}$-doped $\mathrm{ZnO}$ thin films was determined within the wavelength range of $300-500 \mathrm{~nm}$, as given in Figure 4. Except well-defined absorption peak related with wurtzite hexagonal phase $\mathrm{ZnO}$, no other peak related with any impurity was observed which confirms that the synthesized Cd-doped $\mathrm{ZnO}$ multipods possess good optical properties. The optical absorbance spectra and the plots of $(\alpha h v)^{2}$ versus $(h v)$ of Cd doped $\mathrm{ZnO}$ thin films are given in Figure 4a. The direct bandgap values are calculated as $3.18,3.11$, and $3.08,2.98 \mathrm{eV}$ for $1 \%$ at $\mathrm{Cd}, 3 \%$ at $\mathrm{Cd}, 5 \%$ at $\mathrm{Cd}$, and $7 \%$ at Cd-doped $\mathrm{ZnO}$ films respectively. When Cd doping was increased, there was a decrease was shown in the band gap values. the direct band gap of $\mathrm{Cd}$ is approximately $2.5 \mathrm{eV}$ which is lower than that of $\mathrm{ZnO}(\sim 3.3 \mathrm{eV})$, however, they show low resistance due the defect of oxygen vacancies and Cadmium interstitials [31]. It can be seen in Figure 4.b.

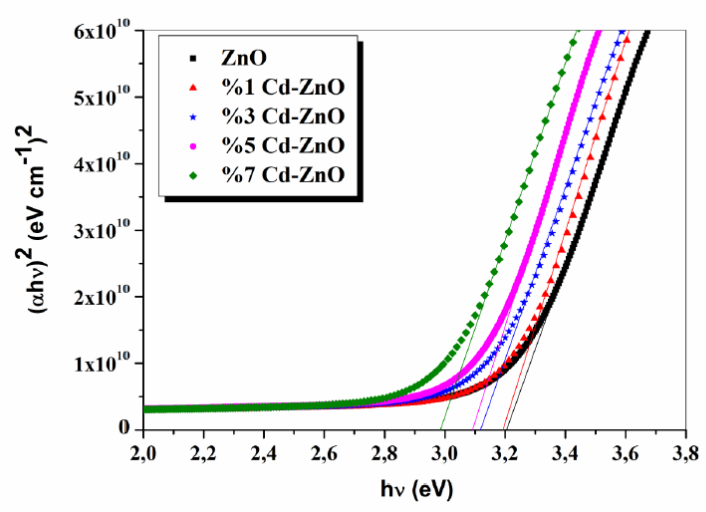

Fig 4a. The optical absorbance spectra and the plots of $(\alpha h v)^{2}$ versus (hv) of Cd doped $\mathrm{ZnO}$ thin films

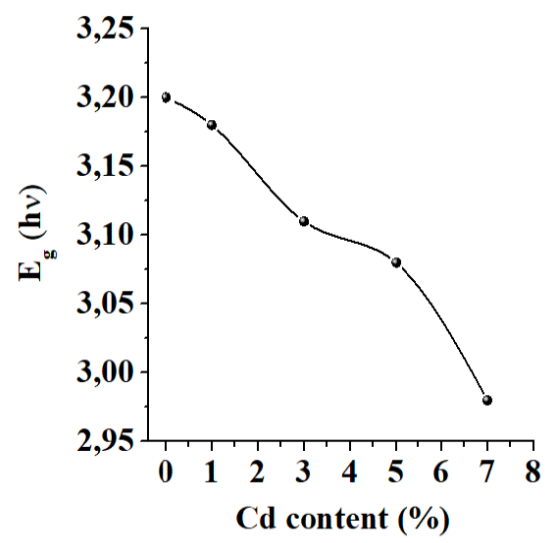

Fig 4.b. The direct bandgap values of $\mathrm{Cd}$ doped $\mathrm{ZnO}$ thin films

Figure 5 gives the resistance of $\mathrm{Cd}$-doped thin films. The resistance values are decreased with increasing $\mathrm{Cd}$ doping concentrations. This shows the decrease in band gap upon $\mathrm{Cd}$ doping by suggesting the possibility of tuning of band gap with doping $\mathrm{Cd}$. These values agree with the literature $[32,33]$. When examining the characteristics of gas sensors, the first parameter to be found is the operating temperature. The operating temperature of the 
sensor may affect its lifetime as well as it may change depending on the target gas sent. It is given in the literature studies that each gas can have different operating temperatures. [3335]. Therefore, the operating temperature of the sensor material produced by sending different gases was first found. In order to determine the optimum operating temperatures, the response of sensors to $100 \mathrm{ppm} \mathrm{NO}, \mathrm{CO}$,ammonia, methanol and acetone were tested as a function of operating temperature ranging from $30{ }^{\circ} \mathrm{C}$ to $250{ }^{\circ} \mathrm{C}$, depicted in Figure $6.5 \%$ at $\mathrm{Cd}$ doped sensors exhibited the high response to $\mathrm{NO}$ as well as the high selectivity compared to other gases. The responses of $3 \%$ at $\mathrm{Cd}$ and $7 \%$ at $\mathrm{Cd}$ sensors were observed to be very close to each other. $1 \%, 3 \%$ and $7 \%$ at $\mathrm{Cd}$ doped $\mathrm{ZnO}$ sensors also exhibited high responses to acetone and $\mathrm{CO}$ apart from the $\mathrm{NO}$ gas. Whereas the operating temperature of NO gas was found $90^{\circ} \mathrm{C}, \mathrm{CO}$ and acetone were $150^{\circ} \mathrm{C}$ and $170{ }^{\circ} \mathrm{C}$. Response was not observed in methanol and ammonia gases. Especially in methanol gas, $250{ }^{\circ} \mathrm{C}$ is still increasing. The best responses were obtained for NO gas. NO is a type of radical and chemically active gas. Therefore, the other gas sensing characteristics were studied only NO gas. This can be explained by the fact that each gas has different binding energies. Thus, they show sensitivity at different working temperatures to break off the surface. In each sensor material produced in the gas sensor studies, it is seen that the target gases show different operating temperatures depending on the production method [33-36].

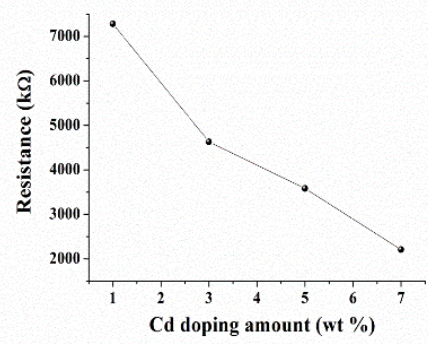

Fig 5. the resistance of Cd-doped thin films.
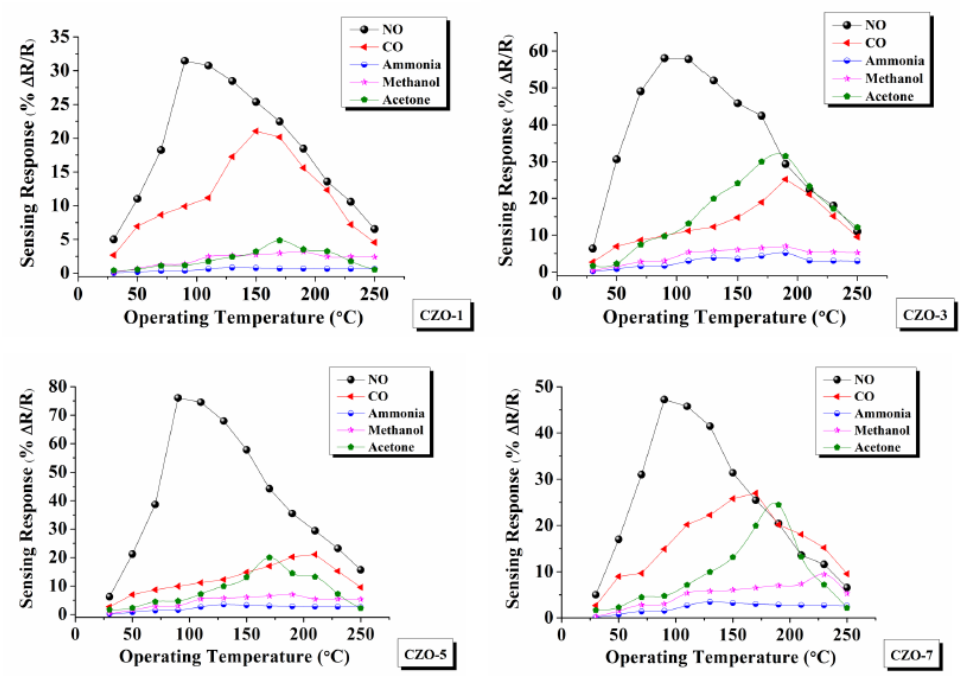

Fig 6. the response of sensors to $100 \mathrm{ppm}$ NO, CO, ammonia, methanol and acetone were tested as a function of operating temperature 
The NO gas concentrations from $0.01 \mathrm{ppm}$ to $100 \mathrm{ppm}$ were tested for all sensors. The response of $0.01 \mathrm{ppm}$ were calculated $1 \%, 7 \%, 12 \%$ and 4 for $1 \%, 3 \%, 5 \%$ and $7 \% \mathrm{Cd}$ doped ZnO respectively, as shown in Figure 7. The response was increased with increasing NO gas concentration in all sensors. It was observed that the response of the sensors increased rapidly when all the sensors were exposed to the target molecules, and the response returned to the initial value [37] when the surface of the sensors was exposed to dry air after each dynamic measurement, as given in Figure 8.
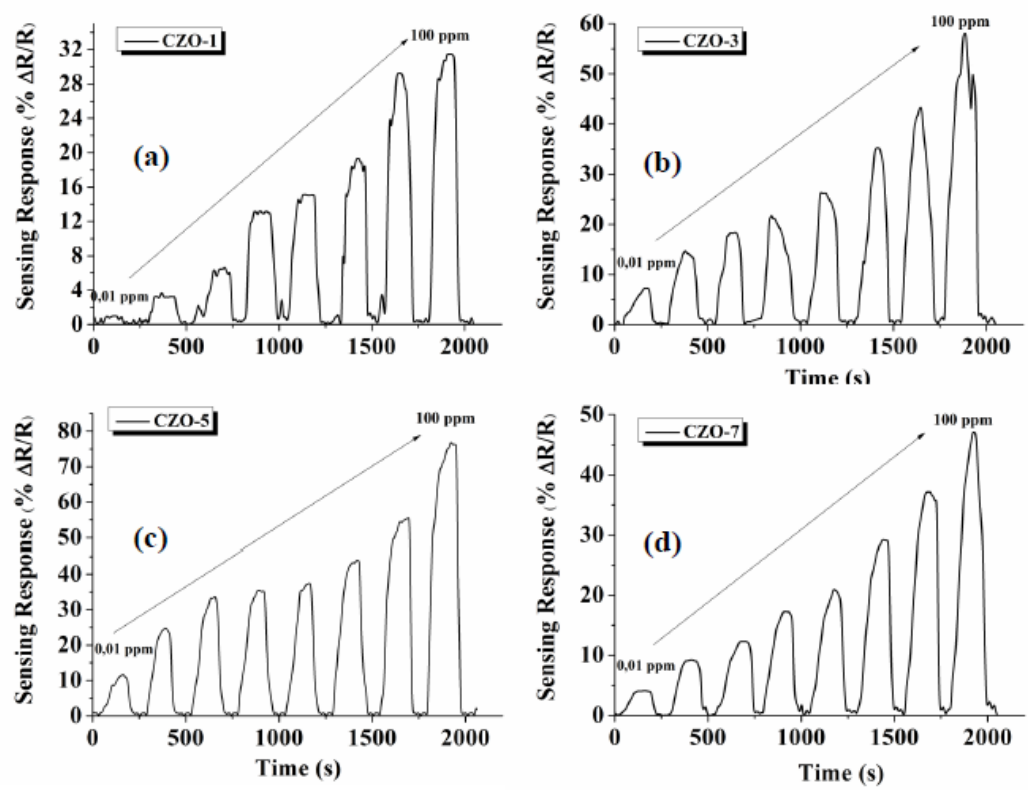

Fig 7. The response to NO gas concentrations from $0.01 \mathrm{ppm}$ to $100 \mathrm{ppm}$

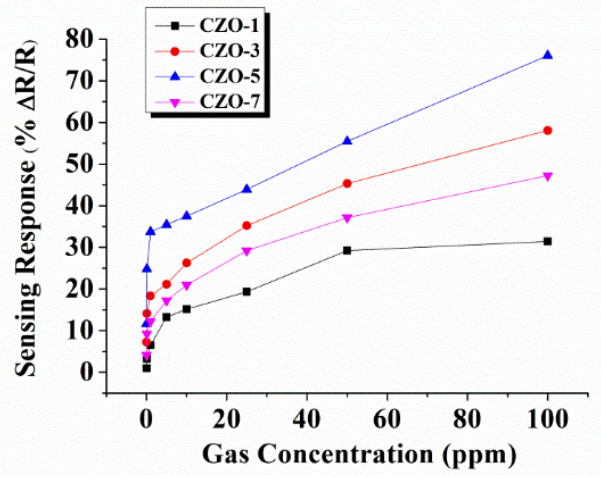

Fig 8 . The response from $0.01 \mathrm{ppm}$ to $100 \mathrm{ppm}$ versus gas concentrations 
Figure 9 depicts the response and recovery times of doped $\mathrm{ZnO}$ sensors. The response and recovery times of sensors were calculated for all NO gas concentrations at operating temperature of $90^{\circ} \mathrm{C}$. It was seen thst CZO5 sensor has the highest response and recovery times.
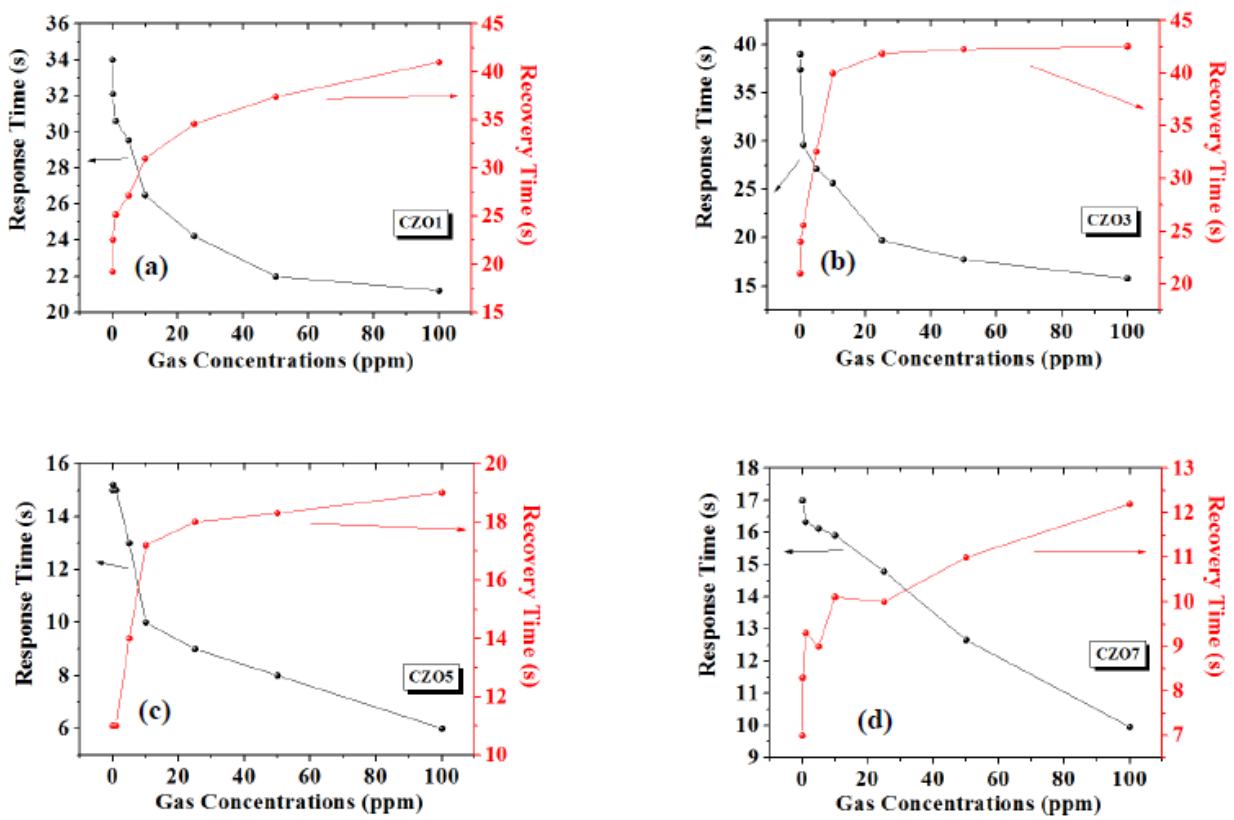

Fig 9. the response and recovery times of doped $\mathrm{ZnO}$ sensors

The detection limit of the sensor is calculated by using Signalto-Nosie approach and the rootmean-square. The root mean square noise $\left(\mathrm{RMS}_{\text {noise }}\right)$ can be obtained by the equations given above [38];

$$
\begin{aligned}
& R_{X^{2}}=\sum\left(y_{i}-y\right)^{2} \\
& R M S_{\text {noise }}=\sqrt{\frac{R_{X^{2}}}{N}}
\end{aligned}
$$

Where $\mathrm{y}_{\mathrm{i}}$ is the response measured experimentally, $\mathrm{y}$ is the average response, and $\mathrm{N}$ is the number of experimental data point.

The sensor noise for $5 \% \mathrm{Cd}$-doped $\mathrm{ZnO}$ sensor is 0.01284 . The detection limit can be thus calculated by the curve-fitting equation as given below [38]:

$$
D L_{(\text {ppm })}=3 \frac{R M S_{\text {noise }}}{\text { slope }}
$$


The detection limit of the sensor to NO is then calculated to be $0.0089 \mathrm{ppm}$. The best results are given by the CZO5 sample. Therefore, other gas sensing parameters such as reproducibility and stability were made only for this sample. Figure 9 shows the reproducibility and stability of CZO5 sample for $0.01 \mathrm{ppm}$ NO gas. Reproducibility measurements were done for 15 cycles. Slight shifts in sensitivity towards the end of the cyles were observed, as seen in Figure 10 (a). However, these are minor shifts that are negligible. The stability of CZO5 sensor was shown in Figure 10 (b). The measurements were carried out for 5 weeks. The sensor exhibited excellent stability.

(a)

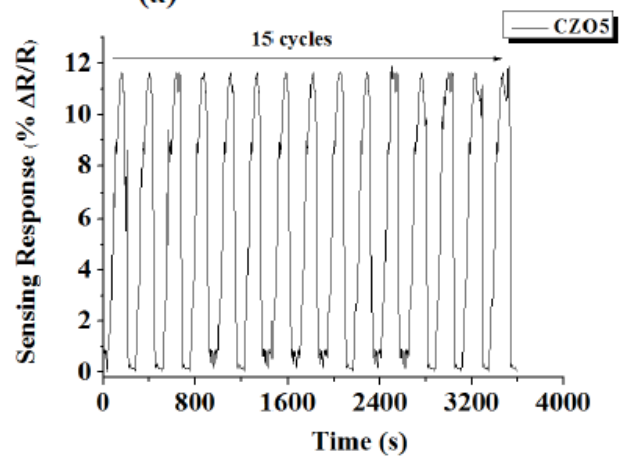

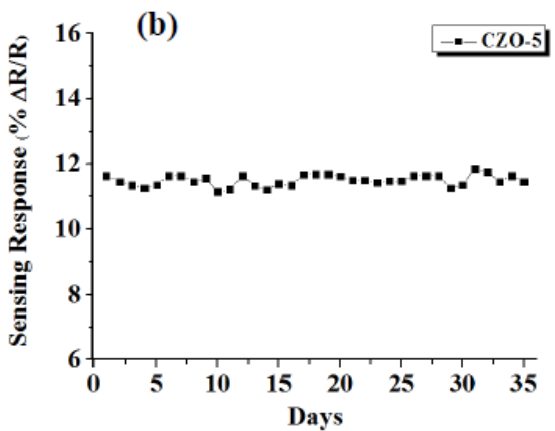

Fig10. Reproducibility measurements (a) The stability (b) of CZO5 sensor

The working principle of the thin film gas sensor can be explained as the change of the amount of carrier electrons on the surface according to the amount of gas in the environment and the measurement of the change in electrical characterization as a result. It is the determination of the change that occurs as a result of chemical or electronic interaction with semiconductor oxide and its surrounding oxide or reducing atmosphere [39]. The mentioned interactions create a change in electrical resistance on the semiconductor surface. In other words, the principle of operation of metal oxide gas sensors can be said to be based on the increase or decrease of electrical resistance as a result of surface reactions by the interaction of oxygen and target gas [40]. By measuring the changing electrical resistance, the concentration change of the target gas can be determined [41]. One of the important factor is doping effect. Cd doping increases the gas response and decreases the operating temperature. This can be associated with the differences in workfunctions of $\mathrm{Cd}$ and $\mathrm{ZnO}$ : $\Phi(\mathrm{Cd})=4.08 \mathrm{eV}$ and $\Phi(\mathrm{ZnO})=4 \mathrm{eV}$, which is assumed to induce electronic sensitization. Moreover, the rectifying Schottky junction at $\mathrm{Cd}-\mathrm{ZnO}$ interfaces to improve electrical transport behavior. According the recent studies, it is seen that $\mathrm{Cd}^{2+}$ metal oxides can act as a kind of Lewis acid on the surface $[42,43]$. In addition, the presence of Lewis acid $\left(\mathrm{Cd}^{2+}\right)$ on the $\mathrm{ZnO}$ surface will significantly reduce the binding energy of another Lewis acid, which can inhibit NO adsorption on the surface, after finding the maximum doping concentration value. Thus, the response of the gas sensor to NO started to decrease after a certain Cd contribution [42-44]. Also, $\mathrm{Cd}^{2+}$, Lewis acid domains can reduce adsorption of NO molecules to the surface, as well as improve the sensor's response response performance. The reduction of the binding energy of NO adsorbed to the surface by $\mathrm{Cd}^{2+}$ as the Lewis acid region facilitates the desorption of $\mathrm{NO}$ and improves the improved recovery performance of the gas sensor [45]. 


\section{Conclusions}

We proposed $\mathrm{Cd}$ doping on the gas sensing properties of $\mathrm{ZnO}$ thin films have been successfully synthesized by Succession Ionic Layer Adsorption and Reaction (SILAR) method. The response of 100 ppm NO gas were obtained $31.45 \%, 58.08 \%, 76.07 \%, 47.23$ $\%$ from $1 \%, 3 \%, 5 \%$ and $7 \%$ Cd-doped ZnO sensors, respectively. In addition, the $5 \% \mathrm{Cd}$ doped $\mathrm{ZnO}$ sensor gas sensing shows a high response of $76 \%$ at $100 \mathrm{ppm}$, and the detection limit is very low (10 ppb) at $90{ }^{\circ} \mathrm{C}$. When tested with different gases (NO,CO, ammonia, acetone and methanol) for $5 \% \mathrm{Cd}$-doped $\mathrm{ZnO}$, the sensor exhibits a good selectivity for $\mathrm{NO}$, excellent stability and repeatability. Overall, this sensor has great potential for developing high-performance gas sensors and can also be applied to the synthesis of many other devices.

\section{Acknowledgement}

The authors acknowledge that this study is supported by ÇAKU scientific research projects unit (BAP-project no: EYO080120B13).

\section{References}

[1] Madhaiyan G, Tung TW, Zan HW, Meng HF, Lu CJ, Ansari A, Chuang WT, Lin HC. (2020) Sensor. Actuator. 320, 128392. https://doi.org/10.1016/j.snb.2020.128392

[2] Tarwal NL, Patil AR, Harale NS, Rajgure AV, Suryavanshi SS, Bae WR, Patil PS, Kim JH, Jang JH. (2014) J. Alloys Compd., 598; 282-288. https://doi.org/10.1016/i.jallcom.2014.01.200

[3] Cai L, Li H, Zhang H, Fan W, Wang J, Wang Y, Wang X, Tang Y, Song Y. (2020).Mat Scl Semicon Proc 118, 105196. https://doi.org/10.1016/i.mssp.2020.105196

[4] Singh P, Mangasa Simanjuntak F, Wu YC, Kumar A, Zan HW, Tseng TY. (2020) J Mater Sci 55:8850-8860. https://doi.org/10.1007/s10853-020-04659-7

[5] Zhu L, Zeng W. (2017) Sens Actuators A Phys 267:242-261. https://doi.org/10.1016/j.sna.2017.10.021

[6] Zhang SL, Lim JO, Huh JS, Lee W. (2012). IEEE Sens J 12:3143-3148. https://doi.org/10.1109/JSEN.2012.2211005

[7] Çorlu T, Karaduman I, Yildirim MA, Ateş A, Acar S. (2017). J Electron. Mater., 46;7, 39954002. https://doi.org/10.1007/s11664-017-5503-Z

[8] Karaduman Er I, Çağırtekın AO, Çorlu T, Yıldırım MA, Ateş A, Acar S. (2019) Bull. Mater. Sci., 42, 32. https://doi.org/10.1007/s12034-018-1714-Z

[9] Galioglu S, Karaduman I, Çorlu T, Akata B, Yıldırım MA, Ateş A, Acar S. (2018) J Mater ScıMater El. 29;2, 1356-1368. https://doi.org/10.1007/s10854-017-8042-8

[10] Erol A, Okur S, Comba B. (2010) Sensor. Actuators B 145:174-80. https://doi.org/10.1016/j.snb.2009.11.051

[11] Li G, Zhang H, Meng L, Sun Z, Chen Z, Huang X, Qin Y. Science Bulletin (Article in Press) (2020). https://doi.org/10.1016/j.scib.2020.05.027

[12] Zhao R, Zhang X, Peng S, Hong P, Zou T, Wang Z, Xing X, Yang Y, Wang Y. (2020) J. Alloys Compd.,813; 152170. https://doi.org/10.1016/j.jallcom.2019.152170

[13] Rouhani F, Morsali A. (2017) New J. Chem. 41; 15475-15484. https://doi.org/10.1039/C7NJ01509G

[14] Chen X, Wang S, Su C, Han Y, Zou C, Zeng M, Hu N, Su Y, Zhou Z, Yang Z. (2020) Sensor. Actuators: B. 305,127393 . https://doi.org/10.1016/i.snb.2019.127393

[15] Tarwal NL, Patil AR, Harale NS, Rajgure AV, Suryavanshi S, Bae WR, Patil PS, Kim JH, $\begin{array}{lllll}\text { Janga } & \text { JH. } & \text { (2014). J. Alloys } & \text { Compd.,598; } & \text { 282-288. }\end{array}$ https://doi.org/10.1016/j.jallcom.2014.01.200

[16] Zhao R, Li K, Wang Z, Xing X, Wang Y. (2018) J. Phys. Chem. Solids 112; 43-49. https://doi.org/10.1016/i.jpcs.2017.08.039 
[17] Bai S, Chen S, Zhao Y, Guo T, Luo R, Li D, Chen A. (2014) J. Mater. Chem. A, 2;16697. https://doi.org/10.1039/C4TA03665D

[18] Naderi H, Hajati S, Ghaedi M, Espinos JP. (2019) Sens. Actuators B, 297; 126774. https://doi.org/10.1016/i.snb.2019.126774

[19] Vinoth E, Gowrishankar S, Gopalakrishnan N. (2017) Materials and Manufacturing Processes, 32, I4. https://doi.org/10.1080/10426914.2016.1244834

[20] Yang X, Wang W, Xiong J, Chen L, Ma Y. (2015) Int. J. Hydrog. Energy. 40; 12604-12609. https://doi.org/10.1016/j.ijhydene.2015.07.086

[21] Yıldırım MA, Tuna Yıldırım S, Ateş A. (2017) J. Alloys Compd., 701, 37-42. https://doi.org/10.1016/i.jallcom.2017.01.092

[22] Yıldırım MA, Ateş A, (2010) Opt. Commun. 283 1370-1377. https://doi.org/10.1016/j.optcom.2009.12.009

[23] Yıldırım MA, Ateş A, (2009) Sens. Actuators A 155 272-277. https://doi.org/10.1016/j.sna.2009.09.002

[24] Gujar TP, Shinde VR, Kim W, Jung KD, Lokhande CD, Joo OS. (2008) Appl. Surf. Sci., 254, 3813-3818. https://doi.org/10.1016/j.apsusc.2007.12.015

[25] Güney $\mathrm{H}$, İskenderoğlu D. (2019) Physica $\quad$ B $552 ; \quad$ 119-123. https://doi.org/10.1016/j.physb.2018.09.045

[26] https://www.webelements.com/periodicity/ionic_radius_2_tet/.

[27] Khalaf KA, Al-Rawas A, Gismelseed A, Al-Ruqeishi M, Al-Ani S, Al-Jubouri A, Al-Ryami K, Al-Jaddedi B. (2019) Advances in Materials 8(2): 70-93 doi: 10.11648/j.am.20190802.15. https://doi.org/10.11648/j.am.20190802.15

[28] Kamble LD, Harale NS, Patil VL, Patil PS, Kadam LD, (2017) Journal of Analytical and Applied Pyrolysis, 127; 38-46. https://doi.org/10.1016/i.jaap.2017.09.004

[29] Phuo PH, Hung CM, Toan NV, Duy NV, Hoa ND, Hieu NV. (2020) Sensor. Actuators A 303;111722. https://doi.org/10.1016/i.sna.2019.111722

[30] Cao PF, Ma SY, Xu XL, Wang BJ, Almamoun O, Han T, Xu XH, Pei ST, Zhang R, Zhang JL, Liu WW. (2020) Vacuum 177 109359. https://doi.org/10.1016/j.vacuum.2020.109359

[31] Ramamurthy M, Yuvaraj P. (2012) International Journal of Science and Research (IJSR), ISSN (Online): 2319-7064; 68-71.

[32] Sampath Kumar AG, Obulapathı L, Sofı Sarmash T, Jhansı Ranı D, Maddaıah M, Subba Rao T, Asokan K. JOM (2015) 67; 834-839. https://doi.org/10.1007/s11837-015-1344$\underline{5}$

[33] Rudra K, Prajapati YK. (2020) Ceram. Intern., 46;8,A; 10135-10141. https://doi.org/10.1016/i.ceramint.2020.01.004

[34] Roshanzamir Modaberi M, Rooydell R, Brahma S, Akande AA, Mwakikunga BW, Liu CP. (2018) Sensor. Actuator. B, 27310; $1278-1290$. https://doi.org/10.1016/j.snb.2018.06.117

[35] Sankar Ganesh R, Durgadevi E, Navaneethan M, Patil VL, Ponnusamy S, Muthamizhchelvan C, Kawasaki S, Patil PS, Hayakaw Y. (2018) Sensor. Actuator. A, 269; 331-341. https://doi.org/10.1016/j.sna.2017.11.042

[36] Mirzaei A, Leonardi SG, Neri G. (2016), Ceram. Int. 42;15119-15141. https://doi.org/10.1016/i.ceramint.2016.06.145

[37] Niu G, Zhao C, Gong H, Yang Z, Leng X, Wang F. (2019), Microsyst Nanoeng.; 5: 21. https://doi.org/10.1038/s41378-019-0060-7

[38] Gu D, Wang X, Liu W, Li X, Lin S, Wang J, Rumyantsev MN, Gaskov AM, Akbar SA. (2020) Sensor. Actuator. B, ,305; 127455. https://doi.org/10.1016/j.snb.2019.127455

[39] Ahmad Naseem Z, Manzoor S, Talib M, Islam SS, Mishra P. (2020) Mater. Sci. Eng., B 255; 114528, https://doi.org/10.1016/i.mseb.2020.114528

[40] Yang CM, Chen TC, Yu-Cheng M, Meyyappan Y. (2019) RSC Adv. 9;23343-23351. https://doi.org/10.1039/C9RA01295H

[41] Chikkadi K, Muoth M, Roman C, Haluska M, Hierold C. (2014) Beilstein J. Nanotechnol. 5, 2179-2191. https://doi.org/10.3762/bjnano.5.227 
[42] Chen X, Wang S, Su C, Han Y, Zou C, Zeng M, Hu N, Su Y, Zhou Z, Yang Z. (2020) Sensor. Actuator. B 305; 127393. https://doi.org/10.1016/i.snb.2019.127393

[43] Rouhani F, Morsali A. (2017) New J. Chem. 41; 15475-15484. https://doi.org/10.1039/C7NJ01509G

[44] Masoomi MY, Beheshti S, Morsali A. (2015) Cryst. Growth Des, 15, 2533-2538. https://doi.org/10.1021/acs.cgd.5b00304

[45] Hu JS, Shang YJ, Yao XQ, Qin L, Li YZ, Guo ZJ, Zheng HG, Xue ZL. (2010) Cryst. Growth Des, 10, 4135-4142. https://doi.org/10.1021/cg1008208 